\title{
Development of Pseudocalanus elongatus (Copepoda, Calanoida) cultured at different temperature and food conditions
}

\author{
W. C. M. Klein Breteler, S. R. Gonzalez, N. Schogt \\ Netherlands Institute for Sea Research, PO Box 59, 1790 AB Den Burg, Texel, The Netherlands
}

\begin{abstract}
The pelagic copepod Pseudocalanus elongatus Boeck was bred 3 times from nauplius stages I and II to maturity at $5,10,15$ and $20^{\circ} \mathrm{C}$ and at 4 different rations of autotrophic and heterotrophic food. The rate of development of the copepods increased with increasing temperature and food supply. The shortest generation times (from egg to adult) were $59 \mathrm{~d}$ at $5^{\circ} \mathrm{C}$ and $19 \mathrm{~d}$ at $15^{\circ} \mathrm{C}$. The generation time nearly doubled when food concentration was very low. At $20^{\circ} \mathrm{C}$ mortality rates were high and development did not proceed faster than at $15^{\circ} \mathrm{C}$. At all food levels the stage duration was generally constant (nearly isochronal), but the last 1 or 2 developmental stages took longer. The relationship between development time and temperature is described by Bělehrádek's functions at different food levels. This relationship predicts a generation time of approximately $45 \mathrm{~d}$ during spring bloom conditions in the North Sea and about 30 d during summer due to food limitation. Field estimates from the literature are too scarce to evaluate the presumption of food limitation during summer conditions. Some evidence of a low critical food level was found compared to other North Sea copepod species. Together with a fast development rate at low temperatures, this may explain the numerical dominance of $P$. elongatus in the North Sea and the northeast Atlantic Ocean.
\end{abstract}

KEY WORDS: Pseudocalanus $\cdot$ Copepods $\cdot$ Cultivation $\cdot$ Development $\cdot$ Temperature $\cdot$ Food

\section{INTRODUCTION}

Growth and productivity of copepods in temperate seas are mainly governed by temperature and food availability. McLaren (1978) discussed the possibility that development rates of copepods in nature are not influenced by variations in food level and that they are predictable from temperature alone. From published data at a wide range of temperatures, Huntley \& Lopez (1992) calculated that temperature alone explained more than $90 \%$ of the variance in growth rate for 33 species of copepods. Although they admitted that the food factor may have been masked by selective predation on slower growing individuals, they proposed that, throughout the ocean, copepods are always able to find sufficient food to grow at maximal rates. This was based on the assumption that micro patches of food in the sea enable zooplankton to graze efficiently, even at low mean food concentrations that are suboptimal only in the laboratory. However, a body of evidence from in situ observations on development, length, weight, condition factor and egg production rates of Acartia spp., Temora longicornis, Oithona similis and Calanus chilensis shows that in temperate seas food can be limiting during a significant part of the season (cf. review by Klein Breteler \& Schogt 1994).

Food limitation may not occur to the same extent in all species of copepods. In particular, different species

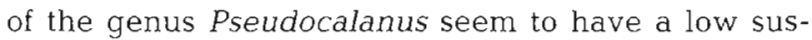
ceptibility to food limitation, which may account for their high abundance in many seas around the world. Compared to the large Calanus spp., grazing rate and egg production in adult Pseudocalanus spp. was satiated at lower food concentrations (Frost 1985). The same was found for development rate at naupliar stages (Green et al. 1991) and for growth rate at copepodite stages (Vidal 1980a). Comparing similar sized species, egg production in $P$. minutus appeared to be less sensitive to discontinuous food availability than in Centropages typicus and Acartia tonsa (Dagg 1977). 
Body length in P. elongatus is another indicator of food limitation (Klein Breteler \& Gonzalez 1982, 1988). In the North Sea there was no effect of food concentration on body length of $P$. elongatus, in contrast to Temora longicornis (Evans 1981). Also in Dabob Bay (Washington, USA) food did not seem to influence body size, growth, development and reproduction of Pseudocalanus sp. (Ohman 1985). However, in Greenland fjords, in the absence of significant seasonal temperature changes, seasonal variations of body size of $P$. minutus were observed that could only be ascribed to differences in the availability of food (Ussing 1938). Obviously, a low sensitivity to food limitation does not mean that Pseudocalanus spp. is food satiated in every area and season. This makes $P$. elongatus a particularly interesting species in which to study the development rate through all stages at controlled conditions of temperature and food concentration. The results can be compared with similar estimates on the small copepods T. longicornis (Klein Breteler \& Gonzalez 1986) and Acartia clausi (Klein Breteler \& Schogt 1994).

Until now, no systematic laboratory analyses on the influence of temperature and food on the rate of development of Pseudocalanus elongatus have been made. The generation time of different species of Pseudocalanus was estimated in the laboratory at a constant temperature and excessive food (Crawshay 1915, Katona \& Moody 1969, Corkett 1970, Sazhina in Corkett \& McLaren 1978, Landry 1983). To establish a new method for estimating median development time, Klein Breteler et al. (1994) added another set of data at a constant temperature and excess food. Different concentrations of food at a constant temperature were used by Paffenhöfer \& Harris (1976), Klein Breteler et al. (1982) and Davis (1983) and different temperatures at excess food by Thompson (1982). The only record on development of Pseudocalanus spp. in relation to both temperature and food concentration is by Vidal (1980b), but that study was restricted to the last 3 copepodite stages. The present study attempts to determine the generation time of $P$. elongatus from the rate of development measured in the laboratory at different conditions of both temperature and food. A temperature range of 5 to $20^{\circ} \mathrm{C}$ was chosen, which covers the habitat of $P$. elongatus throughout the year in its geographic area of distribution (Colebrook 1982, Frost 1989, Fransz et al. 1991). The relationship can be used to interpret field data on the development, with respect to the trophic state, of $P$. elongatus in the sea.

\section{MATERIAL AND METHODS}

The calanoid copepod Pseudocalanus elongatus was continuously cultured in the laboratory under condi- tions of $15^{\circ} \mathrm{C}$ and optimal food ( $\left.>300 \mu \mathrm{g} \mathrm{Cl}^{-1}\right)$ consisting of the autotrophic algae Rhodomonas sp. and Isochrysis galbana and the heterotrophic dinoflagellate Oxyrhis marina (Klein Breteler 1980, Klein Breteler et al. 1982, Klein Breteler \& Gonzalez 1986, 1988). Two chemostat cultures of Rhodomonas sp. (mean Equivalent Spherical Diameter, ESD, $6.7 \mu \mathrm{m}$, mean concentration $1.5 \times 10^{6}$ cells $\mathrm{ml}^{-1}, 33.1 \mathrm{pg} \mathrm{C}$ cell $\left.^{-1}\right)$ and one of $I$. galbana $\left(4.9 \mu \mathrm{m}, 4.2 \times 10^{6}\right.$ cells $\mathrm{ml}^{-1}, 11.7 \mathrm{pg} \mathrm{C}$ cell ${ }^{-1}$ ) were kept at $15^{\circ} \mathrm{C}$ on $\mathrm{f} / 2$ medium (Guillard 1975) at a dilution rate of $0.17 \mathrm{~d}^{-1}$. o. marina lived together with the copepods in the cultures and developed there depending on the supply of autotrophic food and on grazing by the copepods. This organism was also cultured in a 21 continuous culture $\left(14.0 \mu \mathrm{m}, 1 \times 10^{5}\right.$ cells $\mathrm{ml}^{-1}, 215.8 \mathrm{pg} \mathrm{C}$ cell $\left.{ }^{-1}\right)$ that was kept in the dark and fed from a Rhodomonas sp. culture at a dilution rate of $0.23 \mathrm{~d}^{-1}$.

A brood from the parental copepod stock was raised to maturity in 3 independent experiments, each at 4 different temperatures and 4 food supplies of the same food mixture as in the stock culture. The cohorts raised represented the 12th, 20th, and 23th generations bred from February to December 1986.

At the beginning of each experiment, larvae were separated from the parental culture by sieving part of the water through a nylon screen with a mesh of $112 \mu \mathrm{m}$, allowing NI and II with a few eggs to pass. A more synchronised cohort, starting with eggs of known age, was not practical due to the large scale of the experiment. The larvae were concentrated in $3.5 \mathrm{l}$ of the old culture water, mixed well and equally divided into sixteen 251 Fiberglas containers. Sea water of about $30 \%$ was added up to 221 through a Whatman Gamma 12 tube filter (pore size $<2 \mu \mathrm{m}$ ) to a final concentration of 30 to 60 larvae $\mathrm{l}^{-1}$. The temperature was maintained at $5,10,15$ and $20^{\circ} \mathrm{C}\left( \pm 0.2^{\circ} \mathrm{C}\right)$, respectively, by keeping the copepod containers in racks immersed in temperature controlled water basins.

Twice daily time-regulated peristaltic pumps fed 0 , 2, 6 and $30 \mathrm{ml}$ of the mixture of algae to the copepod cultures, representing the Food Supplies 0, 1/16, 1/4 and 1 , respectively. Food Supply 0 merely means that no autotrophic algae were supplied, but it still allowed some copepod growth due to the presence of detritus and small heterotrophic flagellates. These flagellates and the heterotrophic dinoflagellate Oxyrrhis marina occurred in all copepod cultures, since they were introduced with the larvae at the start of the experiments. The trophic state of the cultures depends upon the speed of the food pump and is characterised by a rapidly changing dominance from the small autotrophic flagellates to the larger heterotrophic one. This shift in food species is adequate to meet the changing food size spectrum (Gruzov 1985) of the developing 
larvae (Klein Breteler et al. 1990). After reaching its level, depending on the supply of auto-trophic food, the concentration of $O$. marina remains more or less constant (Fig. 4 in Klein Breteler \& Laan 1993). During this time $O$. marina constituted the dominant food source (45 to $90 \%$ of the total food biomass) and was probably the main food during the later part of the copepod's development (Klein Breteler et al. 1990). When $O$. marina was dominant, its grazing kept the concentration of Rhodomonas sp. below $10 \%$ of the total food biomass. The remaining particles consisted of Isochrysis galbana and similar sized or smaller colourless flagellates and detritus.

Concentrations of algae and Oxyrrhis marina were measured weekly using an Elzone particle counter (Particle Data Inc.). In addition, the concentration of $O$. marina was regularly checked by microscopy by roughly counting the number of living cells present in each sample collected for copepod counting. When the concentration had obviously fallen below the normal level, $O$. marina was added from the continuous culture described above. This manual addition of $O$. marina was sometimes necessary at the end of the experiments, when copepod survival had been high and the grazing capacity of the abundant, almost fullgrown survivors exceeded the growth rate of the heterotrophic flagellate.

There was a clear relation between the microscopic and the electronic counts. However, when no cells were visible the particle counter still recorded some 100 particles $\mathrm{ml}^{-1}\left(\sim 22 \mu \mathrm{g} \mathrm{Cl}^{-1}\right)$ within the size range of Oxyrrhis marina. Also, from the particle distribution, it was clear that particles other than the 3 species used as food were present, particularly in the small size range of Isochrysis galbana. Probably these particles were comprised of detritus and small colourless flagellates. At Food Supply 1 these background particles obviously played no important role $(<10 \%$ of total food biomass), but at the lowest 2 supplies their number may have contributed considerably. Since they also seem to have a food value for the copepods, no attempt was made to correct for their presence. It was assumed that their carbon content was similar to that of the corresponding size class of the regular food. Obviously, the food biomass estimated at lower food supplies was only a rough approximation of the true food level.

The carbon content of the autotrophs was assumed to be constant, since it was obtained from measurements in continuous cultures similar to those of the present experiments. However, Oxyrrhis marina mainly developed in the copepod containers under different conditions. Particle size analyses indicated up to $1.1 \mu \mathrm{m}$ larger cell sizes (mean ESD) at lower temperatures and a high food supply and up to $1.1 \mu \mathrm{m}$ smaller cells at high temperature and low food supply, relative to the size of $O$. marina in the continuous culture. Therefore, the carbon content of $O$. marina was corrected for the corresponding volume deviation.

The concentration and stage of development of the copepods were determined 1 to 3 times per week, depending on the culture conditions. The sampling schedule was chosen so that 9 to 10 samples were taken at regular time intervals during completion of a generation. After stirring, samples were taken with a PVC tube (diameter $4 \mathrm{~cm}$ ) reaching almost to the bottom of the tank. A stopper with a hole on the top and a removable sieve $(50 \mu \mathrm{m})$ on the bottom of the tube allowed easy sampling and collection of the animals in a small petri dish. As a rule 4 samples of 0.251 were taken, but additional samples were taken if fewer than 15 individuals were caught.

Median development time of copepod life stages was determined as the time when $50 \%$ of the population reached a particular stage (Landry 1975, 1983). Until recently, no satisfactory, objective method was available to estimate the median development time. For this reason publication of the present data was suspended until an improved method had been established (Klein Breteler et al. 1994), while data on body size, weight and lipid content of the same experiments were already presented by Klein Breteler \& Gonzalez (1988). According to the new method, Gamma distribution functions were used to fit the cumulative stage frequency data against time. From these functions the median development time of the stages was calculated for each individual culture. Stage duration was calculated as the difference of the median development time of 2 successive stages.

Sexes were discerned, but not treated separately in the calculations. Previous (unpubl.) observations did not indicate any relation between sex ratio and the present culture conditions. Moreover, in contrast to Landry (1983), accurate observations did not reveal a difference in development time between the sexes in 3 species of copepods, including Pseudocalanus elongatus (Klein Breteler et al. 1994).

The number of estimates of stage duration was generally 3 (1 per experiment) for each stage at each culture condition. However, at the youngest naupliar stages, due to their relatively fast development, our sampling frequency appeared to be too low to estimate the median development time. At older stages there were also data gaps when cultures died prematurely. At the most severe condition of $20^{\circ} \mathrm{C}$ and Food Supply 0, the duration of most stages could not be estimated. The durations of the youngest and some missing older stages were derived from the data on the remaining stages. To achieve this, accurate data collected at $15^{\circ} \mathrm{C}$ and excess food (Klein Breteler et al. 1994) were used, assuming equiproportional development (Corkett 1984). Similarly, 
incomplete records from the literature were extrapolated to full generation time using the present results at Food Supply 1 at 5, 10 and $15^{\circ} \mathrm{C}$. Temperature corrections were made using the Bèlehrádek function calculated at Food Supply 1 . The duration of eggs and of the pre-feeding first and second naupliar stage was assumed to be optimal and, at the temperature concerned, not influenced by the food regime.

The generation time $(D, d)$ was calculated as the sum of the duration of all stages, i.e. the time from egg laying to the time when $50 \%$ of the population had reached maturity. The relation with temperature $(T$, ${ }^{\circ} \mathrm{C}$ ) was estimated at different food supplies using Bělehrádek's function:

$$
D=a(T-\alpha)^{b}
$$

according to McLaren (1963, 1965), who showed that a good fit could be obtained at a common value of parameter $b$. However, when trying this we often did not obtain standard errors of the parameters, due to highly correlated parameters, Guerrero et al. (1994) suggested using a model with only 2 parameters to avoid over-fitting. However, both the Arrhenius and the Tauti models they suggested gave bad fits of our data points. Therefore, we simplified Bělehrádek's function to a linear model by adopting a fixed value of parameter $\alpha$. Although this had very little influence on the curves fitted, it enabled confidence intervals (of the regression line) and prediction intervals (of the data) to be calculated. When estimating the 3 parameters iteratively at a common $\alpha_{1}$ the best estimate of $\alpha$ was found to be $-8.0^{\circ} \mathrm{C}$. Therefore, we fixed $\alpha$ at a value of $-8^{\circ} \mathrm{C}$. The parameters of this Bělehrádek's function were estimated by a single linear regression analysis of the form:

$$
y_{i j}=a_{i}^{i}+b_{i}\left(x_{i j}-\bar{x}_{i j}\right)+\varepsilon_{i j}
$$

in which $y=\ln D, x=\ln (T+8), a_{i}^{\prime}=\ln a-b \bar{x}, \varepsilon_{i j}$ is the error which is normally distributed with mean zero and variance $\sigma^{2}$, and $i$ and $j$ are the food supplies and temperatures used, respectively.

In this model $(T+8)$ was corrected for its mean value, to avoid intercepts and slopes that were correlated.
Since a single regression analysis was performed for the total data set of all food levels together, the same number of degrees of freedom and the same number of residual mean squares pertain to all food supplies Hence, the confidence or prediction intervals will be equal, although they will differ proportionally after back transformation.

\section{RESULTS}

The total food biomass increased at higher levels of the supply of autotrophic food (Table 1). The low amount at Food Supply 0 represents a basic concentration of detritus and heterotrophic flagellates, including Oxyrrhis marina. At lower temperatures the total food concentration tended to increase, probably as a result of reduced grazing by the copepods. During the experiments there was no obvious systematic trend, since overall changes of the food concentration were on average close to zero.

The stage duration of Pseudocalanus elongatus in the different experiments is shown in Table 2 . The development proceeded at different rates, depending on temperature and on food supply (Fig. 1). At Food Supply 1 the rate was generaily at maximum, but the difference with Food Supply $1 / 4$ was small. At $20^{\circ} \mathrm{C}$ the development was slightly faster at Food Supply $1 / 4$ than at Food Supply 1. However, the low number of observations at Food Supply 1/4 makes this difference doubtful. From NIV to CIV development was almost isochronal, as is shown from the almost linear progress of development over time, irrespective of the food conditions. However, at $10^{\circ} \mathrm{C}$ this nearly isochronal development was less clear at the higher 3 food supplies. The duration of the first feeding stage NIII was often longer than the other stages (Table 2). At most conditions also the duration of $\mathrm{CV}$ was longer than at younger stages.

The generation time $(D, d)$ is plotted against temperature $\left(T,{ }^{\circ} \mathrm{C}\right.$ ) at different food supplies (Fig. 2). The data at $20^{\circ} \mathrm{C}$ were problematic, because at the lowest food supply the duration of only a few stages was

Table 1 Mean total biomass ( $\mu \mathrm{g} \mathrm{C}^{-1}$ ) of food at different temperatures and food supplies in cultures of Pseudocalanus elongatus. SD: standard deviation; n: number of observations. Food supply is the rate of supplying autotrophic algae; at Supply 0

\begin{tabular}{|c|c|c|c|c|c|c|c|c|c|c|c|c|}
\hline \multirow{2}{*}{$\begin{array}{l}\text { Food } \\
\text { supply }\end{array}$} & \multicolumn{3}{|c|}{$5^{\circ} \mathrm{C}$} & \multicolumn{3}{|c|}{$-10^{\circ} \mathrm{C}$} & \multicolumn{3}{|c|}{$=15^{\circ} \mathrm{C}$} & \multicolumn{3}{|c|}{$20^{\circ} \mathrm{C}$} \\
\hline & Mean & $\mathrm{SD}$ & $\mathrm{n}$ & Mean & $\mathrm{SD}$ & $\mathrm{n}$ & Mean & SD & $n$ & Mean & $\mathrm{SD}$ & $n$ \\
\hline 0 & 64 & 25 & 20 & 54 & 32 & 19 & 60 & 26 & 13 & 54 & 23 & 5 \\
\hline $1 / 16$ & 77 & 22 & 24 & 59 & 14 & 16 & 59 & 13 & 12 & 67 & 18 & 7 \\
\hline $1 / 4$ & 196 & 77 & 22 & 91. & 32 & 11 & 106 & 26 & 9 & 1.06 & 27 & 7 \\
\hline 1 & 655 & 195 & 21 & 363 & 133 & 1.1 & 310 & 80 & 8 & 221 & 54 & 8 \\
\hline
\end{tabular}
some food in the form of detritus and heterotrophic flagellates is present 
Table 2. Pseudocalanus elongatus. Duration (d) of life stages at different conditions of temperature and food. Data estimated from median stage development time observed in 3 separate experiments. Mean values indicated, or, when no data were available, derived [in brackets] from the duration of the other stages at the same condition and from separate experiments at $15^{\circ} \mathrm{C}$ ( $\mathrm{cf}$. 'Material and Methods'). Generation time calculated as the sum of the stage duration of all stages; missing values taken from the column 'Mean' 'Missing estimate of development time of individual stages; hence mean stage duration given of the combined stages. Food supply is the relative pump speed feeding autotrophic algae; at Supply 0 some food in the form of detritus and heterotrophic flagellates is present

\begin{tabular}{|c|c|c|c|c|c|c|c|c|c|c|c|c|c|c|c|c|c|}
\hline \multirow{3}{*}{$\begin{array}{l}\text { Temp. } \\
\left({ }^{\circ} \mathrm{C}\right)\end{array}$} & \multirow{3}{*}{ Stage } & \multicolumn{12}{|c|}{ Food supply } & \multirow{2}{*}{\multicolumn{2}{|c|}{-1}} & \multirow{3}{*}{$\begin{array}{c}\text { Expt } \\
3\end{array}$} & \multirow[b]{3}{*}{ Mean } \\
\hline & & & 0 & 0 & - & & $-1 /$ & 16 & - & & -1 & 14 & - & & & & \\
\hline & & $\begin{array}{c}\text { Expt } \\
1\end{array}$ & $\begin{array}{c}\text { Expt } \\
2\end{array}$ & $\begin{array}{c}\text { Expt } \\
3\end{array}$ & Mean & $\begin{array}{c}\text { Expt } \\
1\end{array}$ & $\begin{array}{c}\text { Expt } \\
2\end{array}$ & $\begin{array}{c}\text { Expt } \\
3\end{array}$ & Mean & $\begin{array}{c}\text { Expt } \\
1\end{array}$ & $\begin{array}{c}\text { Expt } \\
2\end{array}$ & $\begin{array}{c}\text { Expt } \\
3\end{array}$ & Mean & $\begin{array}{c}\text { Expt } \\
1\end{array}$ & $\begin{array}{c}\text { Expt } \\
2\end{array}$ & & \\
\hline \multirow[t]{12}{*}{5} & Egg & & & & {$[7.1]$} & & & & {$[7.2]$} & & & & {$[7.2]$} & & & & [7.1] \\
\hline & 1 & & & & {$[1.8]$} & & & & {$[1.8]$} & & & & {$[1.8]$} & & & & [1.8] \\
\hline & 2 & & & & {$[2.7]$} & & & & {$[2.7]$} & & & & {$[2.7]$} & & & & [2.7] \\
\hline & 3 & 17.9 & 24.8 & 16.3 & 19.6 & 9.4 & 13.2 & 10.7 & 11.1 & $6.8^{\circ}$ & 6.6 & 6.5 & 6.6 & 8.4 & 6.4 & 6.8 & 7.2 \\
\hline & 4 & 9.7 & 8.5 & 14.2 & 10.8 & 6.4 & 4.3 & 5.2 & 5.3 & $6.8^{\circ}$ & 5.4 & 5.0 & 5.8 & 4.4 & 6.7 & 4.2 & 5.1 \\
\hline & 5 & 9.8 & & 17.7 & 13.7 & 7.5 & 5.8 & 2.7 & 5.3 & 5.7 & 5.7 & 3.9 & 5.1 & $3.2^{\circ}$ & 3.4 & 6.1 & 4.2 \\
\hline & 6 & 6.2 & & 14.2 & 10.2 & 3.1 & 3.0 & 4.2 & 3.4 & 1.8 & 1.8 & 2.9 & 2.2 & $3.2^{\circ}$ & 2.9 & 1.3 & 2.5 \\
\hline & 7 & & & -0.5 & -0.5 & 6.2 & 7.1 & 6.8 & 6.7 & 7.8 & 6.0 & 5.4 & 6.4 & 5.3 & 5.7 & 6.6 & 5.9 \\
\hline & 8 & & & & {$[10.5]$} & 3.9 & 4.7 & 4.5 & 4.4 & 3.9 & 4.9 & 7.6 & 5.5 & 6.3 & 4.1 & 4.4 & 5.0 \\
\hline & 9 & & & & {$[10.3]$} & 5.2 & 5.7 & 5.1 & 5.3 & 4.6 & 4.2 & 5.8 & 4.9 & 5.0 & $4.0^{\circ}$ & 3.9 & 4.3 \\
\hline & 10 & & & & {$[10.5]$} & 13.1 & 6.3 & 4.2 & 7.8 & 7.8 & 8.1 & 3.4 & 6.4 & 4.7 & $40^{\circ}$ & 4.0 & 4.2 \\
\hline & 11 & & & & {$[14.6]$} & 11.1 & 8.4 & 10.5 & 10.0 & 5.3 & 7.2 & 5.5 & 6.0 & 6.7 & 12.9 & 8.3 & 9.3 \\
\hline \multicolumn{2}{|c|}{ Generation } & 100.5 & 114.1 & 119.3 & 111.3 & 77.4 & 70.0 & 65.4 & 71.0 & 61.9 & 61.6 & 57.5 & 60.4 & 58.9 & 61.7 & 57.2 & 59.3 \\
\hline \multirow[t]{12}{*}{10} & Egg & & & & {$[3.7]$} & & & & {$[3.7]$} & & & & {$[3.7]$} & & & & [3.7] \\
\hline & 1 & & & & {$[1.0]$} & & & & {$[1.0]$} & & & & {$[1.0]$} & & & & {$[1.0]$} \\
\hline & 2 & & & & {$[1.4]$} & & & & {$[1.4]$} & & & & $\{1.4\}$ & & & & {$[1,4]$} \\
\hline & 3 & & & & {$[7.6]$} & 4.8 & & 5.4 & 5.1 & 4.7 & 4.5 & 4.0 & 4.4 & 3.8 & 4.1 & 3.6 & 3.8 \\
\hline & 4 & & 6.4 & 7.5 & 6.9 & 4.3 & 3.8 & 3.7 & 3.9 & 2.0 & 2.1 & 1.9 & 2.0 & 2.7 & 1.6 & $2.2^{\circ}$ & 2.2 \\
\hline & 5 & 12.1 & $14.2^{\circ}$ & 13.0 & 13.1 & 2.8 & 2.8 & 1.4 & 2.3 & 2.5 & 1.6 & 2.1 & 2.1 & 2.4 & 2.0 & $2.2^{\circ}$ & 2.2 \\
\hline & 6 & 4.4 & $14.2^{\circ}$ & 1.8 & 6.81 & 1.3 & 1.6 & 1.1 & 1.3 & 2.3 & 1.9 & 1.2 & 1.8 & 2.8 & 2.6 & 0.9 & 2.1 \\
\hline & 7 & 2.0 & 0.8 & 4.2 & 2.3 & $1.8^{\circ}$ & 4.0 & 5.4 & 3.7 & 1.8 & 3.6 & 3.4 & 2.9 & 1.5 & 2.2 & 3.5 & 2.4 \\
\hline & 8 & 6.2 . & 3.5 & 3.7 & 4.4 & $1.8^{\circ}$ & $3.4^{\circ}$ & 2.4 & 2.5 & 4.5 & 2.4 & 2.6 & 3.2 & 1.6 & 2.0 & 2.5 & 2.0 \\
\hline & 9 & $6.2^{\circ}$ & 0.8 & 8.0 & 5.0 & 4.1 & $3.4^{\circ}$ & 2.3 & 3.3 & 3.2 & 2.5 & 2.7 & 2.8 & 3.2 & 2.6 & 2.1 & 2.6 \\
\hline & 10 & & 0.3 & 6.1 & 3.2 & 7.5 & $3.4^{\circ}$ & 2.7 & 5.1 & 4.2 & 2.9 & 2.6 & 3.2 & 3.1 & 2.9 & & 3.0 \\
\hline & 11 & & & & {$[8.4]$} & 10.3 & 7.5 & 4.9 & 7.6 & 4.0 & 6.1 & 4.7 & 4.9 & 4.8 & 4.3 & & 4.5 \\
\hline \multicolumn{2}{|c|}{ Generation } & 63.0 & 62.2 & 66.4 & 63.8 & 44.6 & 41.1 & 35.3 & 40.3 & 35.0 & 33.7 & 31.2 & 33.3 & 31.8 & 30.2 & 30.4 & 30.8 \\
\hline \multirow[t]{12}{*}{15} & Egg & & & & {$[2.1]$} & & & & {$[2.1]$} & & & & {$[2.1]$} & & & & {$[2.1]$} \\
\hline & 1 & & & & {$[0.5]$} & & & & {$[0.5]$} & & & & {$[0.5]$} & & & & {$[0.5]$} \\
\hline & 2 & & & & {$[0.8]$} & & & & {$[0.8]$} & & & & {$[0.8]$} & & & & {$[0.8]$} \\
\hline & 3 & & & & {$[4.7]$} & & & & {$[4,0]$} & & 1.9 & & 1.9 & & 1.6 & $1.9^{\circ}$ & 1.7 \\
\hline & 4 & 6.4 & & 4.2 & 5.3 & & $2.3^{\circ}$ & & 2.3 & 2.1 & 2.3 & & 2.2 & & 1.9 & $1.9^{\circ}$ & 1.9 \\
\hline & 5 & & 10.2 & & 10.2 & & $2.3^{\circ}$ & & 2.3 & 1.7 & 1.7 & 2.2 & 1.9 & $1.4^{\circ}$ & 1.2 & 1.3 & 1.3 \\
\hline & 6 & & 1.5 & & 1.5 & 1.6 & 1.6 & & 1.6 & 1.2 & 1.4 & $1.5^{\circ}$ & 1.3 & $1.4^{\circ}$ & 1.7 & 1.1 & 1.4 \\
\hline & 7 & & 3.1 & & 3.1 & 3.9 & 3.4 & & 3.7 & 2.7 & 1.8 & $1.5^{\circ}$ & 2.0 & $1.4^{\circ}$ & 1.9 & 2.0 & 1.8 \\
\hline & 8 & & 2.9 & & 2.9 & 3.2 & 1.4 & & 2.3 & 2.2 & 1.7 & 2.1 & 2.0 & $1.4^{\circ}$ & 1.3 & 1.5 & 1.4 \\
\hline & 9 & & 3.6 & & 3.6 & 3.5 & 4.5 & & 4.0 & 1.3 & 1.3 & 1.6 & 1.4 & 2.4 & 1.5 & 1.4 & 1.8 \\
\hline & 10 & & 1.8 & & 1.8 & 1.9 & 6.6 & & 4.2 & 3.5 & 2.4 & 1.6 & 2.5 & 2.2 & 1.5 & 1.8 & 1.8 \\
\hline & 11 & & 2.4 & & 2.4 & 6.5 & 2.4 & & 4.4 & 2.1 & 2.6 & 5.1 & 3.3 & 2.7 & 2.6 & 3.0 & 2.7 \\
\hline \multicolumn{2}{|c|}{ Generation } & & & & 38.8 & 32.6 & 31.6 & & 32.1 & 22.0 & 20.5 & 22.9 & 21.8 & 20.0 & 18.5 & 19.1 & 19.2 \\
\hline 20 & $\mathrm{Egg}$ & & & & {$[2.9]$} & & & & {$[2.9]$} & & & & {$[2.9]$} & & & & {$[2.9]$} \\
\hline & 1 & & & & {$[0.7]$} & & & & {$[0.7]$} & & & & {$[0.7]$} & & & & {$[0.7]$} \\
\hline & 2 & & & & {$[1.1]$} & & & & {$[1.1]$} & & & & {$[1.1]$} & & & & [1.1] \\
\hline & 3 & & & & & & & & {$[3.4]$} & & & & {$[2.2]$} & 2.6 & 2.4 & & 2.5 \\
\hline & 4 & & 3.5 & 4.0 & 3.8 & 3.8 & 2.9 & 2.2 & 2.9 & 1.8 & 1.5 & & 1.7 & 2.5 & 1.9 & & 2.2 \\
\hline & 5 & & & & & & & 3.3 & 3.3 & 1.1 & 2.3 & & 1.7 & 1.4 & 2.2 & $1.2^{\circ}$ & 1.6 \\
\hline & 6 & & & & & & & 1.7 & 1.7 & 1.6 & 0.4 & & 1.0 & 1.1 & 1.4 & $1.2^{\circ}$ & 1.2 \\
\hline & 7 & & & & & & & 2.5 & 2.5 & 3.1 & $2.9^{\circ}$ & & 3.0 & 2.7 & 2.3 & 1.7 & 2.2 \\
\hline & 8 & & & & & & & & {$[2.7]$} & $1.0^{\circ}$ & $2.9^{\circ}$ & & 2.0 & 1.6 & 1.3 & 2.4 & 1.8 \\
\hline & 9 & & & & & & & & {$[2.7]$} & $1.0^{\circ}$ & 0.7 & & 0.8 & 1.6 & 2.0 & 2.5 & 2.0 \\
\hline & 10 & & & & & & & & {$[2.7]$} & 1.5 & & & 1.5 & 2.9 & 2.8 & 2.1 & 2.6 \\
\hline & 11 & & & & & & & & {$[3.8]$} & 3.4 & & & 3.4 & 2.4 & 2.6 & 3.9 & 3.0 \\
\hline Genera & ation & & & & & & & & 30.4 & 21.3 & 22.2 & & 21.8 & 23.4 & 23.6 & 24.3 & 23.7 \\
\hline
\end{tabular}



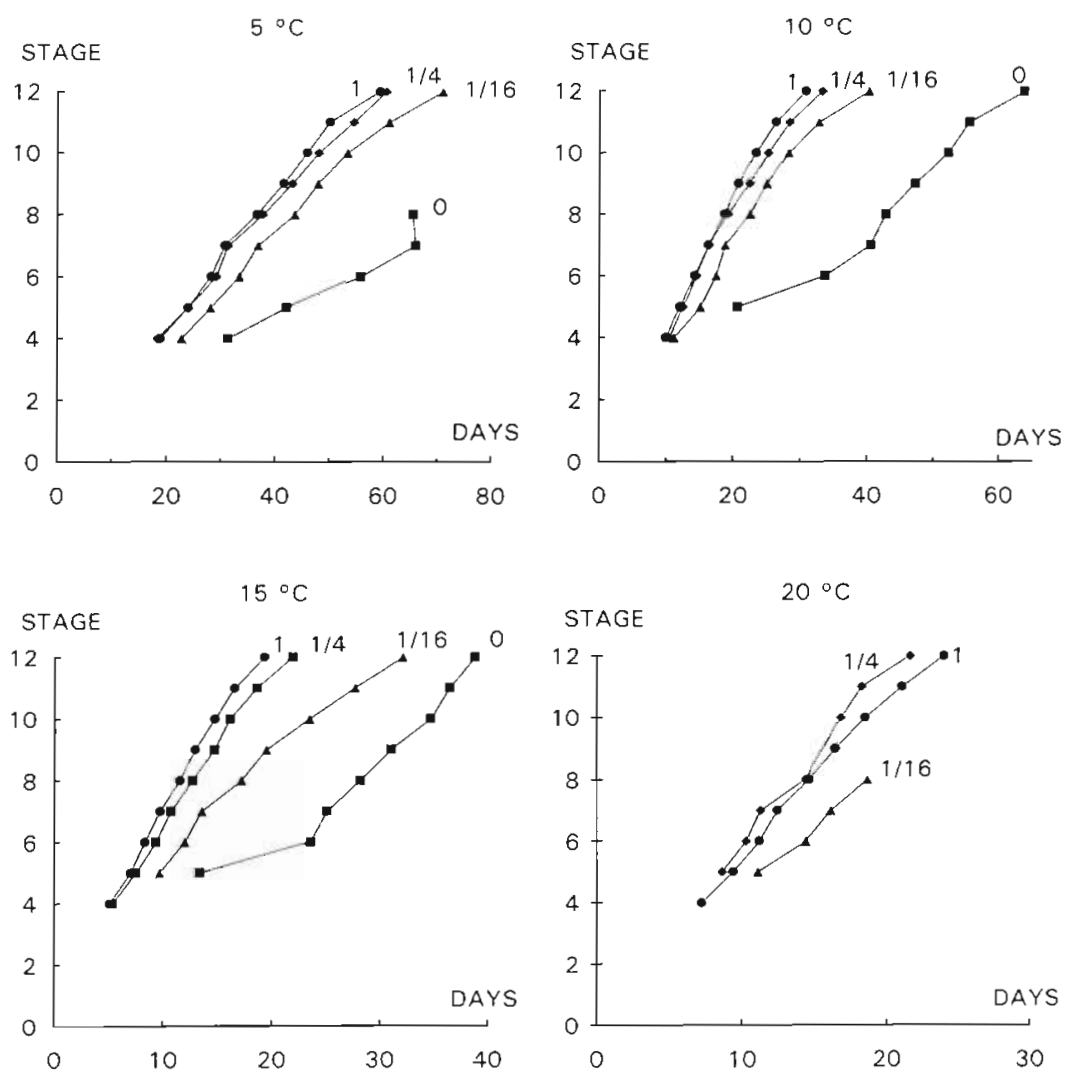

Fig. 1. Pseudocalanus elongatus. Development at $5,10,15$ and $20^{\circ} \mathrm{C}$ and relative food supplies $0,1 / 16,1 / 4$ and 1 . Note that at Food Supply 0 some edible particles are present. Mean age (d) of stages calculated from independently estimated stage duration in each of 3 or fewer experiments of similar conditions. Age at first stage shown estimated from older stages and from separate experiments (cf. 'Material and Methods')

determined (Table 2), and at the higher 2 food supplies the generation time was longer than at $15^{\circ} \mathrm{C}$. Together with the high mortality observed at this temperature (see Table 4), this points to high physiological stress in Pseudocalanus elongatus at the edge of its natural thermal range. Therefore, the data at $20^{\circ} \mathrm{C}$ have not been used in subsequent calculations.

The relationship between generation time and temperature was estimated using Bělehrádek's function, which was transformed to a linear model using a fixed value of $\alpha=-8^{\circ} \mathrm{C}$ (cf. 'Material and methods'). The parameters $a_{1} a^{\prime}$ and $b$ are given in Table 3 . After backtransformation of the linear model, the curves describe the data points between 5 and $15^{\circ} \mathrm{C}$ very well (Fig. 2). Since the data at $20^{\circ} \mathrm{C}$ were not used, the curves should not be extrapolated beyond $18^{\circ} \mathrm{C}$.

The effect of the different food supplies was well established (Fig. 2). Above $6^{\circ} \mathrm{C}$ the $95 \%$ confidence interval of the curve of Food Supply $1 / 16$ does not overlap with that of excess food. There was only a small (nonsignificant) difference between the curves at Food Supplies 1/4 and 1, indicating that Food Supply 1 was excessive. This was similar in experiments with Temora longicornis (Klein Breteler \& Gonzalez 1986) and Acartia clausi (Klein Breteler \& Schogt 1994). At the higher 3 food levels the curves run almost parallel. They maintain a gentle slope at lower temperatures,

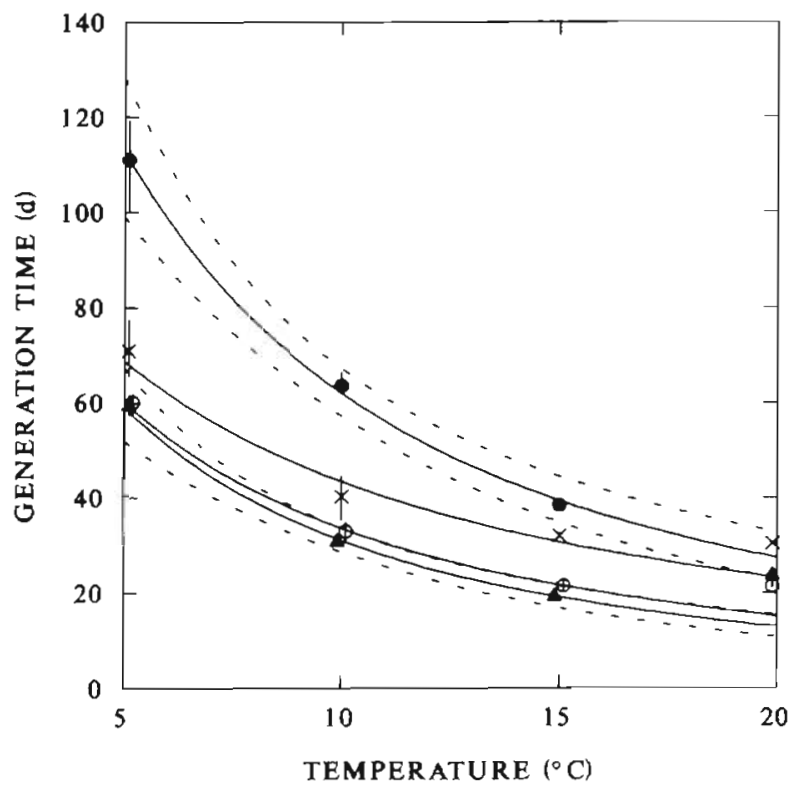

Fig. 2. Pseudocalanus elongatus. Generation time from egg to adult plotted against temperature at Food Supplies $0(\bullet)$, $1 / 16(x), 1 / 4(0)$ and $1(\mathbf{\Lambda})$. Mean values and range (bars), when available, in different experiments (ct. Table 2). Bẻlehrádek's functions (excluding data at $20^{\circ} \mathrm{C}$ ) fitted. $95 \%$ confidence intervals at Food Supplies 0 and 1 given. Intervals at other food supplies not shown since they differ only proportionally 
Table 3. Parameters of Bělehrádek's function $D=a(T-\alpha)^{\mathrm{b}}$ of generation time $(D, \mathrm{~d})$ and temperature $\left(T,{ }^{\circ} \mathrm{C}\right)$ at different food concentrations and $\alpha=-8^{\circ} \mathrm{C} . a^{\prime}$ is the intercept of the linear function. SE: standard error; L: lower limit; H: higher limit

\begin{tabular}{|c|c|c|c|c|c|c|c|}
\hline Food supply & $a^{\prime}$ & $\mathrm{SE}\left(a^{\prime}\right)$ & $a$ & $L(a)$ & $\mathrm{H}(a)$ & $b$ & $\operatorname{SE}(b)$ \\
\hline 0 & 4.18 & 0.029 & 12684 & 9567 & 16730 & -1.84 & 0.123 \\
\hline $1 / 16$ & 3.81 & 0.029 & 2566 & 1935 & 3385 & -1.41 & 0.123 \\
\hline $1 / 4$ & 3.56 & 0.029 & 5873 & 4475 & 7824 & -1.79 & 0.123 \\
\hline 1 & 3.49 & 0.029 & 9398 & 7158 & 12518 & -1.98 & 0.123 \\
\hline
\end{tabular}

which points to the ability of Pseudocalanus elongatus to develop relatively quickly at a low temperature.

Mortality was generally constant during the culture period. The rate of mortality $(Z)$ was calculated during the complete culture period in each culture according to $N_{t}=N_{0} \mathrm{e}^{-Z t}$, in which $N_{0}$ and $N_{t}$ are the concentration of ind. $l^{-1}$ at time 0 and $t$, after correction for mortality due to the sampling, and $t$ is the time of cultivation in d (Table 4). At higher food supplies between 5 and $15^{\circ} \mathrm{C}$ mortality was generally low and, with 1 exception, varied between 0.034 and $0.016 \mathrm{~d}^{-1}$. However, at the lowest food supplies rather high mortalities occurred. At $20^{\circ} \mathrm{C}$ mortality was high at all food supplies, particularly at the lowest supply, which led to extinction of some cultures.

\section{DISCUSSION}

\section{Laboratory estimates}

In the laboratory generation time of Pseudocalanus elongatus has been estimated by different workers at temperatures between 5 and $15^{\circ} \mathrm{C}$ (Fig. 3). When comparing these with the present results, it should be remembered that our prediction intervals are not very sensitive due to the low number of data points on which they are based. Therefore, non-significant differences should be considered with caution. Our previous experiments at $15^{\circ} \mathrm{C}$ (Klein Breteler et al. 1982), after using the present calculation techniques to estimate median development times, show more or less similar generation times at the same food conditions.

Table 4. Pseudocalanus elongatus. Average mortality rate $\mathrm{d}^{-1}$ at different temperatures and food concentrations. Standard errors in parentheses; $n=3$

\begin{tabular}{|c|c|c|c|c|}
\hline Food supply & $5^{\circ} \mathrm{C}$ & $10^{\circ} \mathrm{C}$ & $15^{\circ} \mathrm{C}$ & $20^{\circ} \mathrm{C}$ \\
\hline 0 & $0.089(0.003)$ & $0.095(0.008)$ & $0.189(0.030)$ & $0.555(0.036)$ \\
\hline $1 / 16$ & $0.030(0.007)$ & $0.034(0.012)$ & $0.092(0.058)$ & $0.336(0.027)$ \\
\hline $1 / 4$ & $0.023(0.002)$ & $0.031(0.003)$ & $0.049(0.017)$ & $0.308(0.024)$ \\
\hline 1 & $0.016(0.005)$ & $0.026(0.007)$ & $0.030(0.010)$ & $0.187(0.008)$ \\
\hline
\end{tabular}

At excessive food the generation time was $3 \mathrm{~d}$ longer than in the present experiment. However, recent experiments at similar conditions (Klein Breteler et al. 1994) showed that at $15^{\circ} \mathrm{C}$ the minimum generation time can be $2 \mathrm{~d}$ shorter than in the present experiments. Although these data points are within the $95 \%$ prediction interval (Fig. 3), it is felt that small differences in the culture conditions occurred, possibly connected with the quality of the autotrophic or heterotrophic food. Probably, the shortest generation times represent the optimum conditions.

Obviously, the results by other workers at excessive food conditions give longer generation times than the present results (Fig. 3). Most of the observations are above or just at the edge of the higher $95 \%$ prediction limit of excessive food. The observations by Thompson (1982) between 5 and $15^{\circ} \mathrm{C}$ on Pseudocalanus elongatus clearly support the present relationship between generation time and temperature. However, the 4 to $13 \mathrm{~d}$ higher level suggests that the single food species Isochrysis galbana she used, was not really optimal. Using $I$. galbana as the excessive but sole food source, we also observed (unpubl. obs.) a (significant) delay of the generation time of $P$. elongatus by about $6 \mathrm{~d}$ compared to the present food mixture at $15^{\circ} \mathrm{C}$. Green et al. (1991) raised $P$. elongatus from NI to CI. At the 4 highest food levels of $I$. galbana and after extrapolation to full generation time (cf. 'Material and methods'), their data also point to a slightly suboptimal generation time (difference almost significant, $p=0.05$ ). Paffenhöfer \& Harris (1976), using Thalassiosira rotula as a single food source, reported a generation time of $P$. elongatus that is $5 \mathrm{~d}$ longer ( $\mathrm{p}=0.05$ ) than in our present results at excessive food. Gruzov (1985) explained that the retention efficiencies of different sizes of food is not the same for all life stages. Clearly, the different stages do not have the same qualitative demand of food (Klein Breteler et al. 1990, Peterson et al. 1991). Hence, a narrow size range of a single food species seems to hamper the growth of copepods during particular stages of development. Nevertheless, Katona \& Moody (1969), using a 


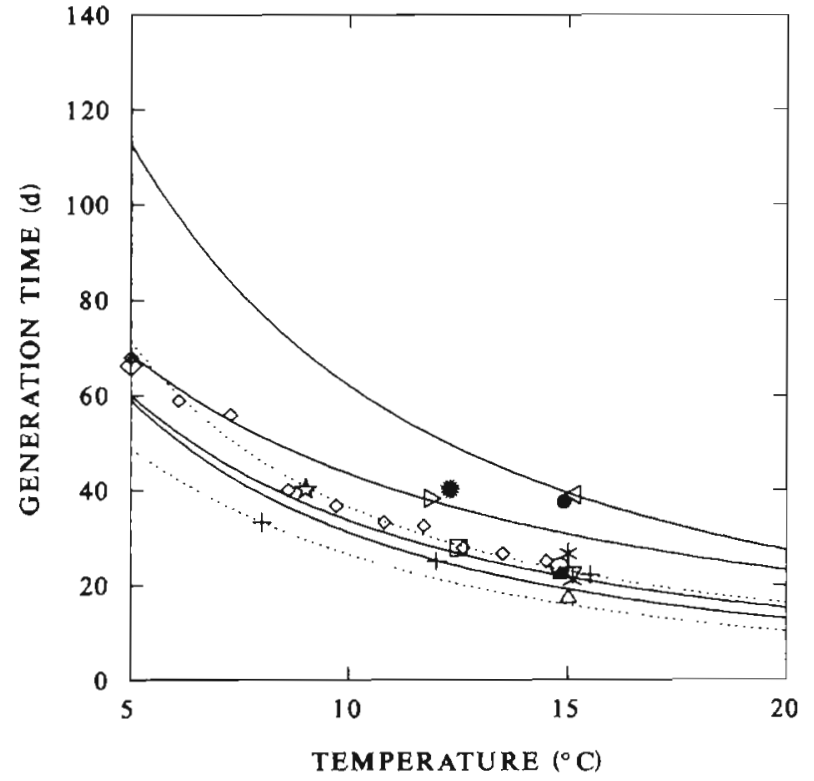

Fig. 3. Pseudocalanus spp. Laboratory estimates of generation time plotted against temperature. Observations by Klein Breteler et al. (1982) at Food Supplies $0(\bullet), 1 / 16(*), 1 / 4$ (O) and $1(4)$ and at excess food by Crawshay (1915) (*), Katona \& Moody (1969) (J). Corkett (1970) (D), Paffenhöfer \& Harris

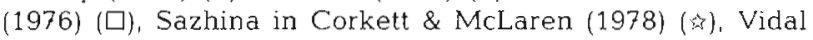
(1980) (+), Thompson (1982) (८), Davis (1983) ( $\diamond)$, Landry (1983) ( $\lambda)$ ), Green et al. (1991) ( $\nabla$ ), and Klein Breteler et al. (1994) ( $\triangle$ ). Most data slightly corrected for missing embryonic development time; those of Green et al. and of Vidal extrapolated for missing development time of all naupliar and copepodite stages, respectively (cf. 'Material and Methods'). Bělehrádek's functions of Fig. 2 at different food supplies $(\longrightarrow$ ) and $95 \%$ prediction interval at Supply $1(\cdots$,$) for$ comparison

mixture of food organisms including ciliate protozoans, observed an extremely long generation time (Fig. 3), which may be explained by the biochemical composition of the food.

Data of unknown or different species of Pseudocalanus (Corkett 1970. Sazhina in Corkett \& McLaren 1978, Davis 1983, Landry 1983) generally indicate a similar generation time as observed by the other workers for $P$. elongatus (Fig. 3). The latter 2 observations are within the $95 \%$ prediction interval of excessive food. The data from Vidal (1980b) were derived by extrapolation of his observations from $100 \%$ CII to $50 \%$ CVI. At 8 and $15.5^{\circ} \mathrm{C}$ his extrapolated data are just at the lower and higher limit of the prediction interval of excessive food, respectively. Also Vidal recognised that the generation time at $8^{\circ} \mathrm{C}$ was suspiciously short and he mentioned the low number of observations as a possible explanation. However, Vidal raised his larvae to $\mathrm{CII}$ at a temperature of 12 or $15.5^{\circ} \mathrm{C}$ and at excess food prior to the measurements at older stages. Hence, particularly at $8^{\circ} \mathrm{C}$, adaptation to the

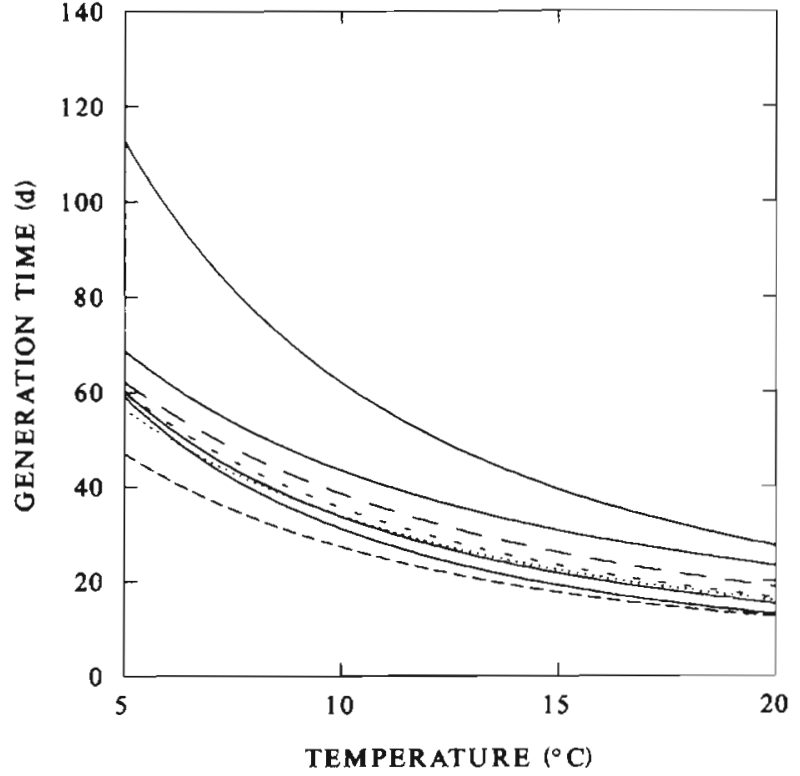

Fig. 4. Pseudocalanus spp. Laboratory estimates of the relation between generation time and temperature by McLaren et al. (1989): P. minutus (- -), P. moultoni $(--)$, P. acuspes $(\cdots \cdots)$ and $P$. newmani (--). Bělehrádek's functions of Fig. 2 at different food supplies ( $\longrightarrow$ ) for comparison

new temperature and food conditions may have biased his results, which may also explain the equally rapid development he noticed at this temperature at low food levels (not shown here).

After the taxonomic status of the genus Pseudocalanus had been clarified, McLaren et al. (1989) studied the development time of the 4 eastern Canadian species separately at temperatures between 0 and $12^{\circ} \mathrm{C}$ at an excess of food supply consisting of a mixture of algae. The Bělehrádek curves he calculated for $P$. minutus, $P$. moultoni and $P$. acuspes run parallel to our curves at Food Supplies 1 and $1 / 4$ at temperatures beyond $8^{\circ} \mathrm{C}$ up to $20^{\circ} \mathrm{C}$ (Fig. 4). Above 7,8 and $10^{\circ} \mathrm{C}$, respectively, the curves of these species predict generation times that are significantly longer $(p<0.05)$ than we observed at Food Supply 1. Below these temperatures the curves increase less steeply, resulting in a generation time of around $60 \mathrm{~d}$ at $5^{\circ} \mathrm{C}$, just as we observed in $P$. elongatus. This is remarkable, since $P$. minutus and $P$. acuspes are species that are considered to be well adapted to the Arctic environment (McLaren et al. 1989). The fourth species P. newmani, however, developed faster at low temperatures. At $15^{\circ} \mathrm{C}$ its generation time was between the present estimate and the one by Klein Breteler et al. (1994) (Fig. 3), but below $13^{\circ} \mathrm{C}$ the curves predict a development time of $P$. newmani that is significantly faster $(p<0.05)$. It is not known what part of the difference among these closely related species must be attributed to the exper- 
imental technique, which can be considerable (Fig. 3). However, observations of embryonic duration (McLaren et al. 1989) support the idea that at least part of the differences may be explained by a different adaptation to the temperature.

\section{Field estimates}

Our experimental observations on the generation time of Pseudocalanus elongatus cover most of the natural range of temperatures and quantity of food. Hence, the Bělehrádek functions calculated permit the interpretation of field estimates of development time with regard to food availability at the prevailing temperature conditions. Unfortunately, only few field estimates of development time of Pseudocalanus spp. are available. Under semi-natural conditions in 4 large enclosures, Hay et al. (1988) estimated the development time from NI to CVI at a temperature increasing from 7.5 to $11^{\circ} \mathrm{C}$. Their estimates, increased by $3.6 \mathrm{~d}$ for embryonic development, lead to generation times that are clearly longer than our estimate at excess food (Fig. 5). Of the 4 differences, 3 are significant ( $\mathrm{p}<$ 0.05). In 2 of the enclosures food must have been severely limiting.

In the southern North Sea, Daro et al. (1982) estimated the generation time at temperatures increasing from $7^{\circ} \mathrm{C}$ in April to $16^{\circ} \mathrm{C}$ in June. Interpolating these temperatures and after correction for egg development as above, their data show optimal or slightly suboptimal development from May to July, but in April/May the development was $8 \mathrm{~d}$ faster than has ever been shown in the laboratory (Fig. 5). In April/May and July the differences with the curve at excess food were significant $(p<0.05)$. This suggests that food was limiting in July, but the unrealistically rapid development rate in April/May points to methodological errors. Although these authors did not specify the temperature accurately, uncertainties of the temperature are not so great since this area of the North Sea is well mixed. However, sampling occurred at one station in an area with considerable vertical advection, so bias due to sampling in water with different phases of development of the copepods is a realistic possibility.

McLaren (1978) used the data of Marshall (1949) to estimate the generation time of Pseudocalanus minutus in Loch Striven during spring and summer. Note that this species probably is $P$. elongatus (Frost 1985 , 1989). McLaren explained that his estimate contained uncertainties about the depth distribution of the copepods and about the ambient temperature that was 2.5 to $6^{\circ} \mathrm{C}$ different between 0 and $30 \mathrm{~m}$ depth. Since Marshall's data pertain to only 1 vertical haul per occasion at 2 depth strata, nothing is known of the

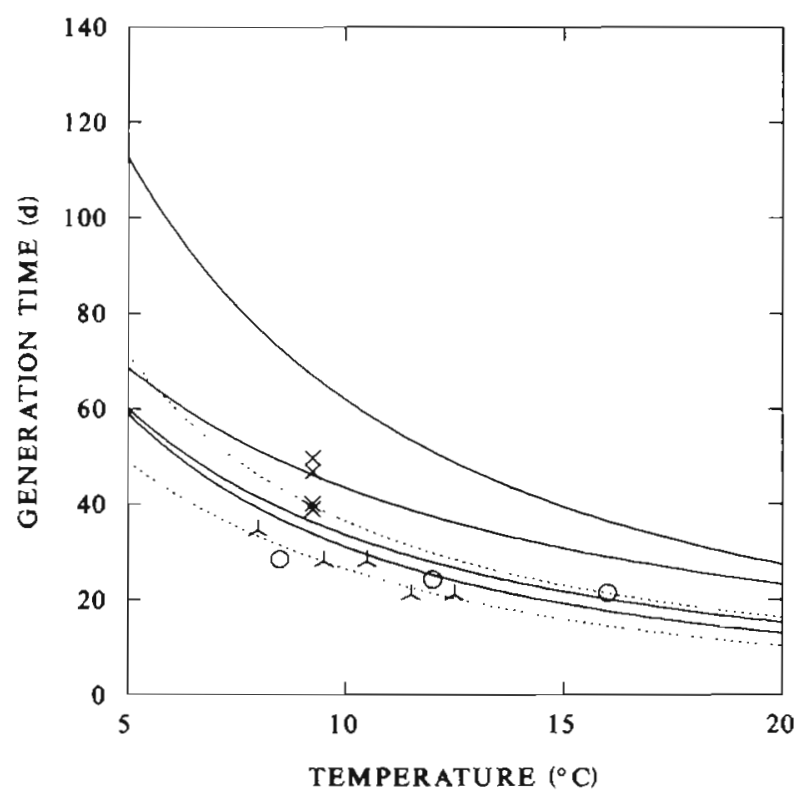

Fig. 5. Pseudocalanus elongatus. Field estimates of generation time observed at different temperatures $\left({ }^{\circ} \mathrm{C}\right)$. Data in Loch Striven from Marshall (1949) by McLaren (1978) ( $\alpha$ ), in the southern North Sea (Daro et al. 1982) (O) and in large enclosures in a Scottish sea loch (Hay et al. 1988) (x). In the latter 2 corrections were applied for missing egg development time. Bělehrádek's functions of Fig. 2 at different food supplies (-) and 95\% prediction interval at Supply $1(\ldots .$.$) for$ comparison

copepod's main residence during the day. If the temperature assumed by McLaren is correct, development in Loch Striven proceeded up to $6 \mathrm{~d}$ faster (2 out of 5 cases significant, $p \leq 0.05$ ) than was possible in the laboratory (Fig. 5). However, if the copepods responded to the surface temperature, development in Loch Striven would still have been 2 and 3 days faster in spring, but 1, 6 and 2 d slower from June to August, respectively, than at excessive food in the laboratory. Most of these differences must be considered as small relative to the accuracy that may be expected in field estimates. Therefore, assuming that the laboratory estimates at excessive food represent the maximal development rate and that the field values were estimated correctly, this would imply that the temperature response of the copepods was not in accordance with the assumed depth distribution, and that food was generally not limiting for development of $P$. elongatus during spring and summer in Loch Striven. The latter conclusion was also drawn by Frost (1985) on the basis of apparently food satiated egg production of this species in the data of Marshall (1949) during spring and summer in Loch Striven. Similar considerations for other species in the same data, however, lead to the conclusion that food was limiting in Calanus finmarchicus (Frost 1985) and possibly also in Acartia 
clausi (Klein Breteler \& Schogt 1994). This supports the idea that $P$. elongatus has a low sensitivity to food limitation (cf. 'Introduction').

The above comparisons between laboratory and field data make it apparent that for a proper interpretation of field data, precise knowledge is required on the distribution and the temperature history of the copepod population. Well-mixed areas with small temporal and spatial temperature gradients include the risk of sampling in different populations. In stratified areas, even when the daily migratory behaviour is known, it will be difficult to estimate an 'average' temperature to which the copepods will physiologically respond during their development. With regard to

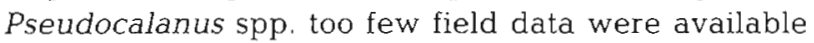
to conclude whether or not food limitation is a general phenomenon in the sea. In a comparable study on Acartia clausi (Klein Breteler \& Schogt 1994) sufficient data were available to conclude that food is generally in short supply during summer.

The present references of unrealistically rapid development may also point to methodological problems in properly estimating the development of copepods in the field. Errors may arise during summer and autumn due to the difficulty to distinguish the successive cohorts when reproduction is continuous (e.g. Krause \& Trahms 1983). This may bias available field estimates towards data that are collected in spring, when the first generation is still clearly discernible. Such over-representation of data in spring, at a surplus of food, might obscure the influence of the food factor during the rest of the season. Moreover, since food concentration and temperature tend to be inversely related during the season, it is difficult to discern the true causal relationship with either temperature or food. For these reasons doubt may arise about the conclusion drawn from literature data that generation time and, derived from this, the growth rate of copepods is determined by temperature alone (Huntley \& Lopez 1992). Too much evidence from field observations, as reviewed by Klein Breteler \& Schogt (1994), is available to generalise and reject food concentration as a limiting factor.

\section{Comparison with other North Sea species}

Temperature had a major influence on development of Pseudocalanus elongatus. At a low temperature of $5^{\circ} \mathrm{C}$ the generation time was about $59 \mathrm{~d}$ when food was abundant. This is comparable to the results obtained with Temora longicornis in similar experiments (Klein Breteler \& Gonzalez 1986). However, Acartia clausi developed some $20 \mathrm{~d}$ slower at this low temperature (Klein Breteler \& Schogt 1994). At a high temperature of $20^{\circ} \mathrm{C}$, differences in development rate were obscured by high mortalities in $P$. elongatus and $T$. longicornis, but not in $A$. clausi. These differences in development rate at low temperatures and in mortality rate at high temperatures are indicative of a species specific physiological adaptation to the temperature. A low tolerance of high temperatures in $P$. elongatus may have contributed to its high mortality observed in the Westerschelde estuary (Soetaert \& Herman 1994) and explain its low abundance during summer in coastal waters (Eriksson 1973, Fransz \& Van Arkel 1983).

Limiting levels of food concentration were clearly found in the present experiments with Pseudocalanus elongatus. Our Food Supply 1/4 only slightly (10 and $15^{\circ} \mathrm{C}$, about $\left.100 \mu \mathrm{g} \mathrm{C} \mathrm{l}^{-1}\right)$ or hardly $\left(5^{\circ} \mathrm{C}_{1} 192 \mu \mathrm{g} \mathrm{C} \mathrm{l}^{-1}\right)$ reduced the rate of development, but at Food Supply 1/16 (about $70 \mu \mathrm{g} \mathrm{C}^{-1}$ ) and lower, development was significantly depressed. In former experiments an optimal development at Food Supply 1/4 was also observed at $15^{\circ} \mathrm{C}$ (Klein Breteler et al. 1982). Therefore, between 100 and $200 \mu \mathrm{g} \mathrm{Cl}^{-1}$ seems to be a critical food level for development in our experiments with P. elongatus. In 3 other species of copepods the rate of development seemed to be more clearly depressed at this food level (Klein Breteler et al. 1982, Klein Breteler \& Gonzalez 1986), although the difference was not very large, particularly with Acartia clausi (Klein Breteler \& Schogt 1994). Therefore, the present results give some support to the low critical food value observed for development and growth in Pseudocalanus spp. compared to Calanus spp (cf. 'Introduction'). However, growth measurements include the change of weight, which, just as body length and lipid content, was generally significantly reduced by food at Food Supply $1 / 4$ in the present experiments (Klein Breteler \& Gonzalez 1988). Hence, with regard to growth the critical food level will be approximately $200 \mu \mathrm{Cl}^{-1}$, which corresponds well with the observations by Vidal (1980a) at the last copepodite stage, but it is clearly higher than found for egg production in Pseudocalanus sp. by Frost (1985).

The critical food level also seems to depend on the quality of the food. Using the chain-forming diatom Thalassiosira rotula as food, Paffenhöfer \& Harris (1976) observed a lower development rate of Pseudocalanus elongatus only at $25 \mu \mathrm{g} \mathrm{Cl}^{-1}$, whereas data of Green et al. (1991), using the small flagellate Isochrysis galbana, provide evidence of reduced naupliar

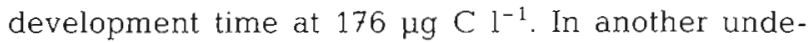
fined species of Pseudocalanus fed with single cells of $T$ eccentrica, Vidal (1980b, his Fig. 3) showed a reduced development rate of copepodite stages at $140 \mu \mathrm{g} \mathrm{C} \mathrm{l}^{-1}$, whereas Davis (1983) reported this at concentrations below $100 \mu \mathrm{g} \mathrm{Cl}^{-1}$ of a mixture of food algae. 
During summer, phytoplankton concentrations of 30 and $70 \mu \mathrm{g} \mathrm{Cl}^{-1}$ are typical in the North Sea offshore and along the coast, respectively (Baars \& Fransz 1984, W. Gieskes \& G. Kraay pers. comm.). At the comparable Food Supplies 0 and $1 / 16$ and a summer temperature of about $18^{\circ} \mathrm{C}$ the present data predict a generation time of Pseudocalanus elongatus of 31 and $26 \mathrm{~d}$, respectively. This is 5 to $9 \mathrm{~d}$ faster than observed in Temora longicornis and 7 to 19 d faster than in Acartia clausi at similarly low food conditions. At spring conditions of about $7^{\circ} \mathrm{C}$ and ad libitum food a generation time of $45 \mathrm{~d}$ would be expected, which is only $4 \mathrm{~d}$ slower than $T$. longicornis, but $17 \mathrm{~d}$ faster than $A$. clausi (Klein Breteler \& Gonzalez 1986, Klein Breteler $\&$ Schogt 1994). These characteristics of a rapid development during spring and summer conditions may explain the numerical dominance of $P$. elongatus in the stratified part of the North Sea and the northeastern Atlantic (Colebrook 1982). First, a possibly low critical food level may help to maintain a larger population during periods of food shortage in autumn and winter and, perhaps, also in summer. Since $P$. elongatus is able to store energy in the form of lipid droplets, the energy reserves collected during winter may contribute to a quick reproductive response at the onset of the spring phytoplankton bloom. Combined with rapid development at low temperatures, an early development of the population may be expected, which is in agreement with the short lag-time after the phytoplankton bloom development compared to $A$. clausi (Colebrook 1982).

Acknowledgements. Drs M. A. Baars and H. G. Fransz critically read the manuscript. J. van der Meer gave valuable advice on statistics. The English text was corrected by Dr K. Ficken.

\section{LITERATURE CITED}

Baars, M. A. Fransz, H. G. (1984). Grazing pressure of copepods on the phytoplankton stock of the central North Sea. Neth. J. Sea Res. 18: 120-142

Colebrook, J. M. (1982). Continuous plankton records: seasonal variations in the distribution and abundance of plankton in the North Atlantic Ocean and the North Sea. J. Plankton Res. 4: 435-462

Corkett, C. J. (1970). Techniques for breeding and rearing marine calanoid copepods. Helgoländer wiss. Meeresunters. 20: $318-324$

Corkett, C. J. (1984). Observation on development in copepods. Studies on Copepoda II. Crustaceana Suppl. 7 . $150-153$

Corkett, C. J., McLaren, I. A. (1978). The biology of Pseudocalanus. Adv. mar. Biol. 15: 2-231

Crawshay, L. R. (1915). Notes on experiments in the keeping of plankton animals under artificial conditions. J mar. biol. Ass. U.K. 10: 555-576

Dagg, M. (1977). Some effects of patchy food environments on copepods. Limnol. Oceanogr. 22: 99-107
Daro, M. H., Hecq, J. H., Bossicart, M., Gysegem, B. van, Tackx, M. (1982). Utilization of primary products by zooplankton. Comm. Meet. int Coun. Explor. Sea C.M.-ICES 1982/1:34 part 3:61-89

Davis, C. S. (1983). Laboratory rearing of marine calanoid copepods. J. exp. mar. Biol. Ecol. 71 119-133

Enksson, S. (1973). The brology of marine planktonic Copepoda on the west coast of Sweden. Zoon 1: 37-68

Evans, F. (1981). An investigation into the relationship of sea temperature and food supply to the size of the planktonic copepod Temora longicornis Müller in the North Sea. Estuar. coast. Shelf Sci. 13: 145-158

Fransz, H. G., Colebrook, J. M., Gamble, J. C., Krause, M. (1991). The zooplankton of the North Sea. Neth. J. Sea Res. 28: 1-52

Fransz, H. G., van Arkel, W. G. (1983). Fluctuation and succession of common pelagic copepod species in the Dutch Wadden Sea. Oceanol. Acta sp: 87-91

Frost, B. W. (1985). Food limitation of the planktonic marine copepods Calanus pacificus and Pseudocalanus sp. in a temperate fjord. In: Lampert, W. (ed.) Food limitation and the structure of zooplankton communities. Arch. Hydrobiol. Beih. 21.1-13

Frost, B. W. (1989). A taxonomy of the marine calanoid copepod genus Pseudocalanus. Can. J. Zool. 67: 525-551

Green, E. R., Harris, R. P., Duncan, A. (1991). The naupliar development of marine calanoid copepods under high and low food conditions. Bull. Plankton Soc. Japan Spec. Vol.: $347-362$

Gruzov, L. N. (1985). Methods of modelling the age dependent ration changes of plankton crustaceans feeding on variable quality of food. Int. Revue ges. Hydrobiol. 70 : $633-655$

Guerrero, F., Blanco, J. M., Rodriguez, V. (1994). Temperature-dependent development in marine copepods: a comparative analysis of models. J. Plankton Res. 16: 95-1.03

Guillard, R. R. L. (1975). Culture of phytoplankton for feeding marine invertebrates. In: Smith, W. L., Chanley, M. H. (eds.) Culture of marine invertebrate animals. Plenum Press, New York, p. 29-60

Hay, S. J., Evans, G. T., Gamble, J. C. (1988). Birth, growth and death rates for enclosed populations of calanoid copepods. J. Plankton Res. 10: 431-454

Huntley, M. E., Lopez, M. D. G. (1992). Temperature-dependent production of marine copepods: a global synthesis Am. Nat. 140: 201-242

Katona, S. K., Moodie, C. F. (1969). Breeding of Pseudocalanus elongatus in the laboratory. J. mar. biol. Ass. U.K. 49: 743-747

Klein Breteler, W. C. M. (1980). Continuous breeding of marine pelagic copepods in the presence of heterotrophic dinoflagellates. Mar. Ecol. Prog. Ser. 2: 229-233

Klein Breteler, W. C. M., Fransz, H. G., Gonzalez, S. R. (1982) Growth and development of four calanoid copepod species under experimental and natural conditions. Neth. J Sea Res. 16: 195-207

Klein Breteler, W. C. M., Gonzalez, S. R. (1982). Influence of cultivation and food concentration on body length of calanoid copepods. Mar. Biol. 71. 157-161

Klein Breteler, W. C. M., Gonzalez, S. R. (1986). Culture and development of Temora longicornis (Copepoda, Calanoida) at different conditions of temperature and food. Syllogeus 58: 71-84

Klein Breteler, W. C. M., Gonzalez, S. R. (1988). Influence of temperature and food concentration on body size, weight and lipid content of two calanoid copepod species. Hydrobiologia 167/168: 201-210 
Klein Breteler, W C. M., Laan, M. (1993). An apparatus for automatic counting and controlling density of pelagic food particles in cultures of marine organisms. Mar. Biol. 116: $169-174$.

Klein Breteler, W. C. M., Schogt, N. (1994). Development of Acartia clausi (Copepoda, Calanoida) cultured at different conditions of temperature and food. Hydrobiologia 297/ 298: $469-479$

Klein Breteler, W. C. M., Schogt, N., Gonzalez, S. R. (1990) On the role of food quality in grazing and development of life stages, and genetic change of body size during cultivation of pelagic copepods. J. exp. mar. Biol. Ecol. 135 $177-189$

Klein Breteler, W. C. M., Schogt, N., Meer, J. van der (1994) The duration of copepod life stages estimated from stage frequency data. J. Plankton Res. 16: 1039-1057

Krause, M., Trahms, J. (1983). Zooplankton dynamics during FLEX '76. In: Sundermann, J., Lenz, W. (eds.) North Sea dynamics. Springer-Verlag, Berlin, p. 632-661

Landry, M. R. (1975). The relationship between temperature and the development of life stages of the marine copepod Acartia clausi Giesbr. Limnol. Oceanogr. 20: 854-858

Landry, M. R. (1983). The development of marine calanoid copepods with comment on the isochronal rule. Limnol Oceanogr. 28: 614-624

Marshall, S. M. (1949). On the biology of the small copepods in Loch Striven. J. mar. biol. Ass. U.K. 28: 45-122

McLaren, I. A. (1963). Effects of temperature on growth of zooplankton, and the adaptive value of vertical migration J. Fish. Res. Bd Can. 20: 685-727

McLaren, I. A. (1965). Some relationships between temperature and egg size, body size, development rate, and fecundity, of the copepod Pseudocalanus. Limnol. Oceanogr 10 : $528-538$

This article was submitted to the editor
McLaren, I. A. (1978). Generation lengths of some temperate marine copepods: estimation, prediction, and implications. J. Fish. Res. Bd Can. 35: 1330-1342

McLaren, I. A., Sévigny, J-M., Corkett, C. J. (1989). Temperature-dependent development in Pseudocalanus species. Can. J. Zool. 67: 559-564

Ohman, M. D. (1985). Resource-satiated population growth of the copepod Pseudocalanus sp. Arch. Hydrobiol. Beih. 21: $15-32$

Paffenhöfer, G.-A., Harris, R. P. (1976). Feeding, growth and reproduction of the marine planktonic copepod Pseudocalanus elongatus Boeck. J. mar. biol. Ass. U.K. 56: $327-321$

Peterson, W. T., Tiselius, P., Kiørboe, T (1991). Copepod egg production, moulting and growth rates, and secondary production, in the Skagerrak in August 1988. J. Plankton Res. 13: 131-154

Soetaert, K., Herman, P. M. J. (1994). One foot in the grave: zooplankton drift into the Westerschelde estuary (The Netherlands). Mar. Ecol Prog. Ser. 105: 19-29

Thompson, B. M. (1982). Growth and development of Pseudocalanus elongatus and Calanus sp. in the laboratory. J. mar. biol. Ass. U.K. 62: 359-372

Ussing, H. H. (1938). The biology of some important plankton animals in the fjords of East Greenland. Meddr. Gronland 100: $1-108$

Vidal, J. (1980a). Physioecology of zooplankton. I. Effects of phytoplankton concentration, temperature, and body size on the growth rate of Calanus pacificus and Pseudocalanus sp. Mar. Biol. 56: 111-134

Vidal, J. (1980b). Physioecology of zooplankton. II. Effects of phytoplankton concentration, temperature, and body size on the development and molting rates of Calanus pacificus and Pseudocalanus sp. Mar. Biol. 56: 135-146

Manuscript first received: June 20,1994

Revised version accepted: December 18, 1994 